\title{
Opinion of Pharmacists Towards Accessibility of Physically Disabled People to Pharmacy
}

\author{
Aslı CULDUZ, Nazlı ŞENCAN, Duygu İĞNECİ, Çiğdem KASPAR, Rukiye ÖZGÖREN, Esra ÇELİK
}

\begin{abstract}
AIM: This study aims to determine, the accessibility of physically disabled persons to community pharmacy. Other objectives are understanding the sensitivity of pharmacists to disability and pharmacists' desire to change.

METHOD: A web survey is used to collect the data. Survey questions are prepared by the researchers which includes demographic information and 14 open and/or closed ended questions related to pharmacy size, location, suitability of pharmacy placement and pharmacists knowledge on disabled laws and etc. In 2011 a priliminary face to face survey had been performed in Kayışdağı-Atasehir region. Then in 2012 wider spread survey was performed via web, through all pharmacies of İstanbul and the data of web survey was collected in two months at January-March, 2012.

RESULTS: The survey applied to community pharmacists; over $50 \%$ of the pharmacists have declared that their pharmacies are not suitable for access by disabled people. $91 \%$ of pharmacies' placement area found to be satisfactory as meter square.
\end{abstract}

Pharmacists believe that necessary arrangements are needed and the responsibility belongs to the government agencies. However, only $41 \%$ of pharmacists are aware of the legal arrangements for disabled citizens. $27 \%$ of community pharmacists stated that, their pharmacies have fully compatible and $54 \%$ of them pointed out that their pharmacy have some deficiencies in habitat.

CONCLUSION: It has been found that community pharmacies are partly accesible for phsically disabled people. This condition is not only pharmacy related, but also caused by many architectural problems in the neighbourhood of pharmacy. It appears that, presence of legislations could not solve the architectural problems itself. Primarily standard measurements should be implemented by government authorities. However, legislation implementions may not enough for and education is needed to improve the thoughts and behaviours of public and health professionals.

KEY WORDS: disability, accessibility to pharmacy, pharmacy, patient satisfaction
Asli Culduz

Yeditepe University, Faculty of Pharmacy, Pharmacy Management Department, Research and Teaching assistant, Atasehir, Istanbul-Turkiye.

Nazlı Şencan

Yeditepe University, Faculty of Pharmacy, Pharmacy Management Department, Atasehir, Istanbul-Turkiye.

Duygu İğneci, Rukiye Özgören

Pharmacist

Çiğdem Kaspar

Yeditepe University, Faculty of Medicine, Medical Informatics and Biostatistics Dept., Atasehir, Istanbul-Turkiye.

Esra Çelik

Bilim Pharmaceuticals, Medical Deapartment, Maslak-Istanbul.

\section{INTRODUCTION}

Disability is a part of the human condition. Almost everyone at some point in life may be temporary or permanent, and those who survive to old age corrupted functioning can experience increasing difficulties. Responses to disability have been changing since the 1970 s, prompted largely by the self-organization of people with disability and by the growing tendency to see disability as a human rights issue. Historically, people with disabilities have largely been provided through solutions that segregate them, such as residential institutions and special schools-but Turkey is newly developing about this situation. Disabled policy has now shifted towards community and educational inclusion, and medically focused solutions have given way to more interactive approaches recognizing that people are disabled by environmental factors as well as by their bodies (1).

The United Nations estimates that there are 788 million persons with disabilities in the world today (2). This number is increasing every year due to factors such as war and destruction, unhealthy living conditions, or the absence of knowledge about disability, its

\author{
Correspondence: \\ Asli Culduz \\ Email: aslıculduz@yeditepe.edu.tr
}


causes, prevention and treatment. There are around ten million disabled people in Turkey. Turkey Disability Survey at 2002, shows that $49,99 \%$ of orthopedic disabled people have difficulties caused by inaccessebility to buildings and its surroundings. Impairments and disabilities may disadvantage the individual by limiting or preventing the fulfillment of six important 'survival' roles: orientation, physical independence, mobility, occupation, social integration and economic self sufficiency (3).

According to research from around the world, disabled persons living facilities in order to provide a variety of services performed by the local improvement greatly impaired, re-acquired by the society. Rearrangements introduced by the Turkish Disability Act also make it unlawful to directly discriminate against someone wrongly perceived to be disabled or to treat someone less favourably because of an association with or link to a disabled person.

The majority of persons with disablities live in less developed countries where people lack access to essential services such as health care. It is known that many governments and civil associations try to increase mostly employment, education and health services of the disabled persons.

Community pharmacies are first step health care service and consultation. Therefore, accessing to a pharmacy, provides primary health care service. Every individual have right to be free, have right to be able to provide their own needs. However, limited but promising developments do not provide community pharmacy's accessibility for disabled persons.

\section{DEFINITIONS OF DISABILITY}

Disability is a complex phenomenon, reflecting an interaction between features of a person's body and features of the society in which he or she lives. The definitions are several and supplementary;

United Nations described the term as "those who have long-term physical, mental, intellectual or sensory impairments which in interaction with various barriers may hinder their full and effective participation in society on an equal basis with others" in Convention on the Rights of Persons with Disabilities (4).

In Turkish Disability Act, defines the "Disabled is the person who has difficulties in adapting to the social life and in meeting daily needs due to the loss of physical, mental, psychological, sensory and social capabilities at various levels by birth or by any reason thereafter and who therefore need protection, care, rehabilitation, consultancy and support services" (3).

According to World Health Organization, disabilities is an umbrella term, covering impairments, activity limitations, and participation restrictions. An impairment is a problem in body function or structure; an activity limitation is a difficulty encountered by an individual in executing a task or action; while a participation restriction is a problem experienced by an individual in involvement in life situations (5).

Disability should be viewed neither as purely medically nor as purely socially. Persons with disabilities can often experience problems arising from their health condition. A balanced approach is needed to see the different aspects of disability. The "International Classification of Functioning, Disability and Health" adopted as the conceptual framework, understands functioning and disability as a dynamic interaction between health conditions and contextual factors, both personal and environmental (1).

The below terms are also important in understanding and contextualising the phenomenon;

Impairment; any temporary or permanent loss or abnormality of a body structure or function, whether physiological or psychological. An impairment is a disturbance affecting functions that are essentially mental (memory, consciousness) or sensory, internal organs (heart, kidney), the head, the trunk or the limbs.

Disability; a restriction or inability to perform an activity in the manner or within the range considered normal for a human being, mostly resulting from impairment.

Handicap; this is the result of an impairment or disability that limits or prevents the fulfilment of one or several roles regarded as normal, depending on age, sex and social and cultural factors (6).

These three terms are used interchangeably. In this paper "disability" term is chosen and used, which is more suitable for Turkish language. In Turkey, disability rates, classifications, diagnostics are made according to international criteria for disability prepared on the basis of disability classification. Disability determination criteria and application are practised by the Ministry of Finance, Ministry of Health, Labour and Social Security Ministry and the Presidency Administration for Disabled People jointly with the Ministry of National Education to be issued. According to the law in Turkish National Legislation; disability defined as congenital or acquired for any reason, the physical, mental, spiritual, social life due to loss of sensory and social skills to adapt to various degrees and the daily requirements and challenges of prevention, care, rehabilitation, counseling and support services people need.

\section{Disability population in Turkey}

There is not enough information on the number and proportion of disabled people and people having chronic illnesses and also their socio- economic characteristics. Disabled people have important differences in realizing their living activities because of the cause and probability of the appearance time of disability varying according to the age. That is why, "the orthopedical, visually, hearing, speech, mental disability" and "chronic illness" were all examined in two different groups in this section.

Total disability proportion in the overall population of Turkey is $2.29 \%$. The proportion of orthopedically, visually, hearing, speech and mentally disabled people is $2.58 \%$ and the proportion of people having chronic illnesses is $9.70 \%$ as well. When the proportion of these disabilities is examined by age groups, it is observed that proportion of disabled people increases in older ages. This is especially observed in people having chronic illnesses. While the proportion of orthopedically, seeing, hearing, speaking and mentally disabled people is higher in rural, the proportion of people having chronic illnesses is higher in urban (7).

The main problems that the disabled people face consists; transportation, housing and physical environment problems. Physical environment has a great importance for disabled people because of their physical limitations. While a habitat is designed or a model of society is practised for everyone, living in it, should be considered. Physical environments such as roads, pavements, public buildings, parks and gardens, schools, houses and transport vehicles pose serious challenges for disabled people to be involved in the society (8). 
There has not been enough done to make living easier for disabled people in the cities. The slopes constructed without suitable standards and some improper practices do not make life easier for the disabled but may cause more people to become disabled. A project was undertaken Matthews and Vujakovic (9) with ten wheelchair users regarding their personal geography, an urban mapping exercise and their way of seeing urban places. The results of these researches (10) can be summerized as follows; high kerbs and/or of dropped kerb, steep gradients or ramps, uneven paving slabs, rough or cobbled surfaces, slippery surfaces, narrow pavements, handrails not provided on ramps, steps without adjacent ramps.

As in many countries, individuals with disabilities are facing various problems as it is in Turkey. These barriers prevent the disabled persons from gaining equal access to information, education, employment, public transport, housing, social / recreational opportunities and health care. It is obvious that social, structural, psychological barriers may affect the access to services (Figure 1). These barriers adversely affect the people with disabilities to access to anywhere such as hospitals, health care centers and mainly as this paper focuses to pharmacies.

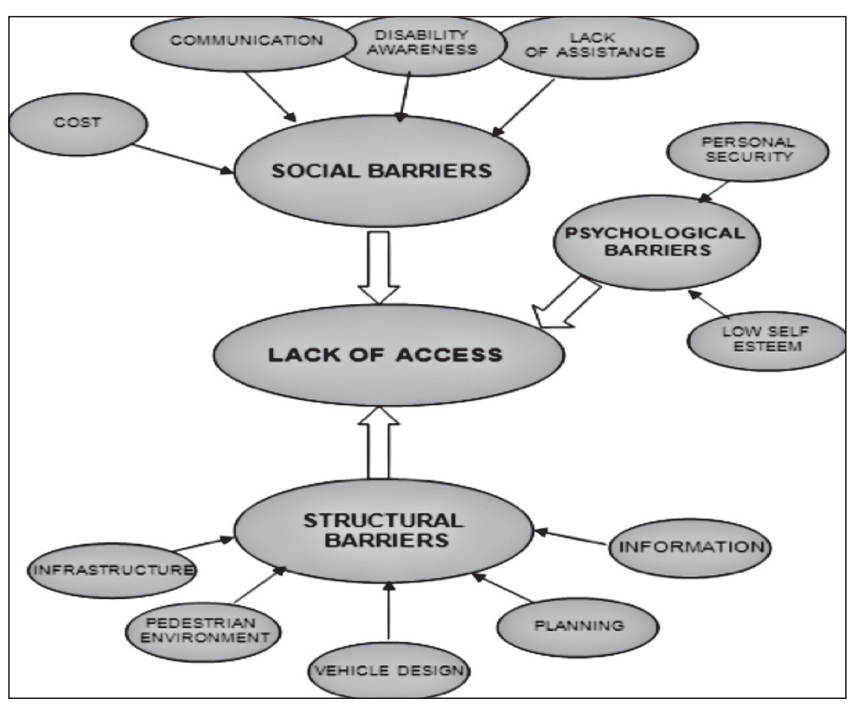

Figure 1: Barriers for disabled people

One of the most easily available health care service for patients are pharmacies and pharmacies need to be easily accessible for disabled patients. However this may be unlikely by disabled people. In this regard, especially patients with physical disabilities may fall with some difficulties.

\section{AIM}

This study aims to determine, community pharmacy's accessibility for physically disabled persons. Other objectives are understanding the sensitivity of pharmacist to disability and pharmacists' desire for improvement. The design of the study can be characterized as both descriptive and determinative. It is a new attempt to describe pharmacies which are primary health care providers in terms of accessibility for disabled people. It is determinative in terms of the attempt to put forward a data on pharmacies' current state.

\section{METHOD}

A web survey is used for collecting the data. The survey included demographic information and also open and/or closed ended questions related to pharmacy size, location, suitability of the disabled access to pharmacy and pharmacists knowledge on laws and etc. In 2011 a priliminary face to face survey was performed to pharmacists in Kayışdağ1-Atasehir region. This wide spread survey is performed via web, through all pharmacies of İstanbul. The data of web survey was collected in two months at JanuaryMarch, 2012.

Data analysis technique: The data are collected as electronic document and analyzed by descriptive statistics SPSS PC software. This data collection aims to find the relationship between demographic characteristics and other parameters.

\section{RESULTS}

The number of pharmacists who participated the survey is 141 . Since the number of pharmacist that filled the survey are not enough to create a meaningful statistics, results are given as frequencies (numbers) and as proportions.

Table 1: Gender Distribution

\begin{tabular}{|c|c|c|}
\hline Gender & $\mathrm{n}$ (frequency) & $\%$ (percentage) \\
\hline Female & 87 & 61,7 \\
\hline Male & 54 & 38,36 \\
\hline Total & 141 & 100,0 \\
\hline
\end{tabular}

Most of the participants were female and the distribution of years of experinece in the pharmacy is similar.

Table 2: Years of experience

\begin{tabular}{|c|c|c|}
\hline & $\mathrm{n}$ (frequency) & $\%$ (percentage) \\
\hline Less than 5 years & 29 & 20.6 \\
\hline 5 to 10 years & 26 & 18.4 \\
\hline 10 to 20 years & 40 & 28.4 \\
\hline 20 to 30 years & 29 & 20.6 \\
\hline More than 30 years & 17 & 12.1 \\
\hline Total & 141 & 100.0 \\
\hline
\end{tabular}

Particular accumulation was not observed in the range of year of study.

Table 3: Ownership of pharmacy

\begin{tabular}{|c|c|c|c|}
\hline & & n (frequency) & $\%$ (percentage) \\
\hline Rent & & 112 & 79.4 \\
\hline Ownership & & 28 & 19.9 \\
\hline Other & & 1 & 7 \\
\hline & Total & 141 & 100.0 \\
\hline
\end{tabular}

To be a property owner of pharmacy is an important criteria for the suitability of the pharmacy and like it is supposed most of the pharmacists are renter. Although pharmacists' store are not usually 
$(\% 79.4)$ in their own property, they may make modifications at store as suitable for disabled people, especially related entrance of pharmacy.

Table 4: Pharmacy location

\begin{tabular}{|c|c|c|}
\hline & $\begin{array}{c}\mathrm{n} \\
\text { (frequency) }\end{array}$ & $\begin{array}{c}\% \\
\text { (percentage) }\end{array}$ \\
\hline Closed to or within the shopping center & 5 & 3.5 \\
\hline Nearest health center & 57 & 40.4 \\
\hline Neighborhood pharmacy & 57 & 40.4 \\
\hline $\begin{array}{l}\text { Close to the shopping center and health } \\
\text { center }\end{array}$ & 2 & 1.4 \\
\hline $\begin{array}{l}\text { Close shopping center and neighborhood } \\
\text { pharmacy }\end{array}$ & 1 & 7 \\
\hline \multirow[t]{2}{*}{$\begin{array}{l}\text { Close to the health centers and } \\
\text { neighborhood pharmacy }\end{array}$} & 19 & 13.5 \\
\hline & 141 & 100.0 \\
\hline
\end{tabular}

It is declared that, mostly the pharmacies are either near to an health center or in a neighbourhood.

Table 5: Size of the pharmacy

\begin{tabular}{|c|c|c|}
\hline & $\mathrm{n}$ (frequency) & $\%$ (percentage) \\
\hline Less than $35 \mathrm{~m}^{2}$ & 3 & 2.1 \\
\hline Between $35 \mathrm{~m}^{2}-50 \mathrm{~m}^{2}$ & 60 & 42.6 \\
\hline Between $50 m^{2}-100 m^{2}$ & 69 & 48.9 \\
\hline Greater than $100 \mathrm{~m}^{2}$ & 9 & 6.4 \\
\hline Total & 141 & 100.0 \\
\hline
\end{tabular}

According to the results obtained; all pharmacies are big enough for disableds. Pharmacy size may effect the disable suitability of inside and outside decoration. Pharmacies which are 50-100 $\mathrm{m}^{2}$ and greater than this size, may be more suitable for accessibility of the disabled patients.

Table 6: The definition of "physically handicapped/disability"

\begin{tabular}{lcccc}
\hline & \multicolumn{2}{c}{ Yes } & \multicolumn{2}{c}{ No } \\
\hline & $\begin{array}{c}\text { n } \\
\text { frequency }\end{array}$ & $\begin{array}{c}\text { \% } \\
\text { percentage }\end{array}$ & $\begin{array}{c}\text { n } \\
\text { frequency }\end{array}$ & $\begin{array}{c}\text { \% } \\
\text { percentage }\end{array}$ \\
\hline Congenital disabled & 128 & 90.8 & 13 & 9.2 \\
$\begin{array}{l}\text { Injured, plastered, } \\
\text { wrapped, surgical, }\end{array}$ & 85 & 60.3 & 56 & 39.7 \\
broken leg & & & & \\
$\begin{array}{l}\text { Absent leg or short legs } \\
\text { because of polio or other } \\
\text { diseases }\end{array}$ & 131 & 92.9 & 10 & 7.1 \\
$\begin{array}{l}\text { Elder person have } \\
\text { difficulty of walking }\end{array}$ & 115 & 81.6 & 26 & 18.4 \\
$\begin{array}{l}\text { Walker and similar } \\
\text { device user }\end{array}$ & 125 & 88.7 & 16 & 11.3 \\
Wheelchair user & 136 & 96.5 & 5 & 3.5 \\
$\begin{array}{l}\text { A permanent crutch user } \\
\text { Temporary crutch user }\end{array}$ & 131 & 92.9 & 10 & 7.1 \\
Have had polio & 79 & 56.0 & 62 & 44.0 \\
\hline & 116 & 82.3 & 25 & 17.7 \\
\hline
\end{tabular}

According to predicted results; people who have had polio, permanent crutch users, wheelchair users and people who have walking difficulty because of age are generally perceived as disabled people.

Table 7: Can temporary-disabled persons (broken leg, limitation after operations,...) be defined as disabled?

\begin{tabular}{|c|c|c|}
\hline & $\mathrm{n}$ (frequency) & $\%$ (percentage) \\
\hline Yes & 68 & 48.2 \\
\hline No & 73 & 51.8 \\
\hline Total & 141 & 100.0 \\
\hline
\end{tabular}

While some of respondents have ben implicated temporary disability in classification of disability, nearly half of them did not agree.

Table 8: Do you think people who have temporary disability need to be treated with special service or special behavior?

\begin{tabular}{|c|c|c|}
\hline & $\mathrm{n}$ (frequency) & $\%$ (percentage) \\
\hline Yes & 127 & 90.1 \\
\hline No & 14 & 9.9 \\
\hline Total & 141 & 100.0 \\
\hline
\end{tabular}

Nearly all respondents declared that, solicitude services should be given to disabled person in pharmacy. Although temporary disabilities do not accept in the disability classification from many authorities, pharmacists included in the classification of disabilities. Respondents said that these persons have same problems to access to pharmacy and health care providers as reason for their classification.

Table 9 : Do you have any disabled person in your family?

\begin{tabular}{|c|c|c|}
\hline & n (frequency) & $\%$ (percentage) \\
\hline Yes & 19 & 13.5 \\
\hline No & 122 & 86.5 \\
\hline Total & 141 & 100.0 \\
\hline
\end{tabular}

According to declaration of the respondents, only nineteen pharmacists have disabled relatives in their family. All the pharmacists should empathised to the matter as an health care giver.

Pharmacists declared that $6.4 \%$ of their patients are physically disabled, $8.5 \%$ are mentally disabled and $4.3 \%$ are sensory disabled (This ratios are only pharmacists perception). It is also understood that disabled patients mostly reach to the pharmacy services via their family. Also, it should be considered that family may not have mention their disabled family member while having any service. It could be thought that disabled persons reaching pharmacies via their families might be a lot than it is noticed within consideration of this possibility. 
Table 10: Evaluating pharmacy habitat for accesibility for physically disabled people

\begin{tabular}{lcccccc}
\hline & \multicolumn{2}{c}{ Appropriate } & \multicolumn{2}{c}{ Partly App. } & \multicolumn{2}{c}{ Not available } \\
& $\begin{array}{c}\mathbf{n} \\
\text { frequency }\end{array}$ & $\begin{array}{c}\text { \% } \\
\text { percentage }\end{array}$ & $\begin{array}{c}\mathbf{n} \\
\text { frequency }\end{array}$ & $\begin{array}{c}\text { \% } \\
\text { percentage }\end{array}$ & $\begin{array}{c}\text { n } \\
\text { frequency }\end{array}$ & $\begin{array}{c}\text { \% } \\
\text { percentage }\end{array}$ \\
\hline $\begin{array}{l}\text { Neigh- } \\
\text { boorhood }\end{array}$ & 22 & 15.6 & 63 & 44.7 & 56 & 39.7 \\
$\begin{array}{l}\text { Street of } \\
\text { pharmacy }\end{array}$ & 51 & 36.2 & 50 & 35.5 & 40 & 28.4 \\
$\begin{array}{l}\text { Foot } \\
\text { pavements }\end{array}$ & 33 & 23.4 & 56 & 39.7 & 52 & 36.9 \\
$\begin{array}{l}\text { Entrance } \\
\text { of } \\
\text { pharmacy }\end{array}$ & 78 & 55.3 & 39 & 27.7 & 24 & 17.0 \\
$\begin{array}{l}\text { Door of } \\
\text { pharmacy }\end{array}$ & 82 & 58.2 & 40 & 28.4 & 19 & 13.5 \\
$\begin{array}{l}\text { Inside of } \\
\text { pharmacy }\end{array}$ & 110 & 78.0 & 26 & 18.4 & 5 & 3.5 \\
\hline
\end{tabular}

Opinions of appropiateness of the area around the pharmacy has varieties. Rates of appropiateness of the area around the pharmacy increases from outside to inside. Most of the pharmacists declared that, inside of the pharmacy is appropriate for disabled patients but outside the pharmacy the streets, foot pavements are partially or not appropriate. In addition, most of pharmacists said that pharmacy entrances' are not suitable for accessibility of disabled patients. Pharmacists mentioned that this problem is based on local government (municipality) because they failed down on arrange physical environment for disabled accessebility.

Table 11: Knowledge of regulations for pharmacy entrance

\begin{tabular}{|c|c|c|c|}
\hline & & n (frequency) & $\%$ (percentage) \\
\hline Yes & & 58 & 41.1 \\
\hline No & & 83 & 58.9 \\
\hline & Total & 141 & 100.0 \\
\hline
\end{tabular}

The pharmacist asked about regulations related to pharmacy. The question was like that: "Did you know that according to a lesilation of 1997, ensuring accessibility of disabled to public spaces including pharmacy, entrances and foot pavements is mandatory in Turkey?" Most of the pharmacists declared that they didn't know about the legislation. Pharmacists, should have been informed through the social security institutions and professional pharmacy associations.

Table 12: Do you think your pharmacy and area around your pharmacy are appropiate for this legislation and accessibility for disabled people?

\begin{tabular}{|c|c|c|}
\hline & $\mathrm{n}$ (frequency) & $\%$ (percentage $)$ \\
\hline Appropriate & 38 & 27 \\
\hline Not available & 27 & 19.1 \\
\hline $\begin{array}{l}\text { There are some deficiencies } \\
\text { can be corrected }\end{array}$ & 76 & 53.9 \\
\hline Total & 141 & 100.0 \\
\hline
\end{tabular}

When it is asked for pharmacists suggestion and prediction for the future arrangements, different answers were given. Most of the pharmacists seem to have courage to improve the environment for disabled patients. Pharmacists declared that "increasing education, architectural modifications of foot pavements and stairs" need to be renewed. Also, one of the pharmacist have stated that "disabled people do not have to fit our environment, we have to change and arrange the environment for them ".

\section{CONCLUSION AND DISCUSSION}

This descriptive research is designed to draw a general view of pharmacists point for disabled patients and their access to the pharmacies. Accessibility of disabled people and patients to the community pharmacies in Turkey is the concern which have to be improved.

The result indicates that community pharmacies are not completely suitable for access of physically disabled people. Many pharmacies are not accessible physically because of outside environment. Also some of the pharmacies are not accessible because of the entrance, door of the pharmacy store. According to legislations ensuring accessibility of disabled to public spaces including pharmacy entrances, foot pavements is mandatory. Some pharmacists are aware of legislations and they want to be a part of change. However, some of pharmacists accuse the government for current state or do not believe that legislations are applicable and have difficulty in practice. In addition, pharmacists are willing to serve to the disabled patient via his/her family.

At the time of the resarch this legislation was not followed up regularly by either government organizations or pharmacy chambers. Follow up researches in the following years may show the effectiveness of the regulations and improvements both for patient satisfaction and pharmacy services.

Although, every pharmacist was enthusiastic to subject and have few disabled relative, only number of them wanted to take into action. Some of them expect the change from government and are not voluntering to create a change. This shows that education and creating awareness on disabled persons entegrating to life is stil needed.

Most of the pharmacies can not determine a definite number about their disabled patients. This situation may have several reasons. One of them is different classifications of disabled people that pharmacists has made. Thus, different numbers mentioned at survey could be explained. Other factor is relatives and friends that bought medicines for disabled people. This condition makes it impossible for pharmacists to determine a definite number of disabled people. Thus, they cannot notice the importance of the problem.

As a conclusion, the accesibility of community pharmacies for phsically disabled people and understanding pharmacists' point of view about disability at community pharmacies in Istanbul is enabled. It has been found that community pharmacies are partly accesible for phsically disabled people. This condition is not only pharmacy related, but also caused by many architectural problems in the neighbourhood of pharmacy. It appears that, presence of legislations could not solve the architectural problems itself. Application of standard measurements should be implemented by 
government authorities primarily. However, legislation implementions also are not enough for itself, education will improve the thoughts and behaviours of public and health professionals. Pharmacists believe in change and they may participate or contribute to.
Limitations of the study: There are 3850 pharmacists listed to Istanbul Chamber of Pharmacists. However only 141 pharmacists answered the survey. The participation rate is low as $3.7 \%$. Generally young and curious pharmacists use internet and web, so the generalization of the results may be limited.

\section{Fiziksel engelli hastaların eczane ve eczacl- lık hizmetlerine erişimi}

AMAÇ: Bu çalışma, fiziksel engelli hastaların eczane ve eczacılık hizmetlerine erişim durumunu tanımlamayı amaçlamıştır. METOT: Bilgi toplamak amacı ile web anketi hazırlanmış ve uygulanmıştır. Anket soruları araştırmacılar tarafından hazırlanmıştır. Ankette, demografik sorular ve 14 tane açı ve/veya kapalı uçlu biten sorularl ile eczanenin büyüklüğü, yeri, engelli hastaların erişimine uygunluğu ve eczacıların konuyla ilgili yasalar ile ilgili sorulardan oluşmaktadır. İlk anket çalışması, yüzyüze olarak, 2011 yılında Kayışdağı/ Ataşehir bölgesindeki eczane eczacıları ile yapılmıştır. 2012 yılı Ocak-Mart aylarında çalışma genişletilmiş ve web anketi haline getirilerek, İstanbul genelindeki eczacılara uygulanmıştır.

BULGULAR: Eczane eczacılarına uygulanan anket sonuçları değerlendirildiğinde, eczanelerin $\% 50$ ' den fazlasının engelli hastaların erişimi için uygun olmadığı bildirilmiştir. Eczane- lerin \%91 'inde metrekare alanın uygun olduğu anlaşılmaktadır. Resmi otoritenin sorumlu olduğu ve yeni düzenlemelere ihtiyaç duyulduğu vurgulanmıştır. Bununla birlikte eczacıların, sadece \%41'i engelli hastalar için yapılan düzenlemelerden haberdardırlar. Eczacıların \%27'si eczanelerinin çevresinin tamamen uygun olduğunu, \%54'ü ise eksiklerinin bulunduğunu belirtmişlerdir.

SONUÇ: Eczanelerin engelli hastalar için kısmen erişelibilir olduğu sonucuna ulaşılmıştır. Bu durumun sadece eczaneyle ya da eczacıyla alakalı olmadığı, eczanenin çevresinden kaynaklı bazı yapısal faktörlerin durumu etkilediği tespit edilmiştir. Gerekliliklerin yerine getirilmesi resmi otoritenin uygulamalarına bağlıdır. Ancak, mevzuat uygulamları yeterli gözükmemektedir. Eğitim ile halkın ve sağlık personellerinin konuyla ilgili düşüncelerinin ve davranışlarının geliştirilmesi gerekmektedir.

ANAHTAR KELIMELER: engellilik, engellilerin eczaneye erişimi, eczane, hasta memnuniyeti

\section{REFERENCES}

1. World report on disability, 2011, WHO, Available from http:// whqlibdoc.who.int/publications/2011/9789240685215_eng.pdf?ua $=1$ (accessed 27 January 2014)

2. Available from http://www.worldbank.org/en/topic/ (accessed 27 January 2014)

3. Turkish Disability Act, Available from http://www.ozida.gov.tr/ ENG/?menu=legislation\&sayfa=act (accessed 27 January 2014)

4. Convention on the Rights of Persons with Disabilities, Available from http://www.un.org/disabilities/convention/conventionfull.shtml, (accessed 27 January 2014)

5. Health Topics,Disabilities, Available from http:/www.who.int/topics/ disabilities/en/ (accessed 27 January 2014)

6. Barbotte E, Guillemin F, Chau N. Prevalence of impairments, disabilities, handicaps and quality of life in the general population: a review of recent literature. Bul of the World Health Organ, 2001, 79: $1047-55$.
7. Turkish Disability Survey Available from http://www.ozida.gov.tr/ arastirma/tr_ozurluler_arastirmasi/graf.pdf (accessed 27 January 2014)

8. Dünya Engelliler Vakfı, Engelsiz Şehir Tasarım Raporu Available from http://www.devturkiye.org/Projeler/Engelsiz-Sehir-Planlamasi/ Engelsiz-Sehir-Tasarim-Raporu/?phpMyAdmin=rljdgPQ20IOfLkB3P kJ1V2hi3ya (accessed 27 January 2014)

9. Matthews MH, Vujakovic P. Private worlds and public places: mapping the environmental values of wheelchair users. Environment and Planning. 1995; 27, 1069-83.

10. Gümüş DÇ. "The attitudes of responsible local agencies towards disability", Thesis for the graduate school of natural and applied sciences, Middle East Technical University, Ankara, 2008.

Acknowledgement: Thanks to Istanbul Chamber of Pharmacists (ICP) and Pharm. Semih Güngör for their support and approval. 